\title{
Utilization of Modified Soybean Oil in Passenger Car Radial Tyre Tread and Sidewall Compound to Promote Green Mobility
}

\author{
Arnab Dutta, Jagannath Chanda, Tirthankar Bhandary, Abhijit Pal*, Sanjit Kumar Das, Saikat Dasgupta, \\ Rabindra Mukhopadhyay \\ Hari Shankar Singhania Elastomer and Tyre Research Institute (HASETRI), Raghupati Singhania Centre of Excellence, 437, Hebbal Industrial Area, \\ Mysore-570016, Karnataka, India \\ *Corresponding author; Email: abhijitpal@ymail.com, Cell phone: +91-9332996799
}

DOI: 10.29322/IJSRP.11.06.2021.p11458

http://dx.doi.org/10.29322/IJSRP.11.06.2021.p11458

\begin{abstract}
Over the past 10 to 15 years, the tyre industries globally have tried to diminish the petrochemical load to contest its fluctuating price and most importantly the associated health issues. A large number of agriculture and forest based green materials were examined as an alternative to the petroleum product for this purpose in the rubber industries. In the present study potential of vegetable oils known as modified soybean oil (MSO), as substitute of petroleum oil were explored in the tyre tread compounds and sidewall compound. Petroleum based oil treated residual aromatic extract TRAE is taken in control compound for all the formulation where carbon black (CB) is used as reinforcing filler. Two different compounds based on Natural Rubber (NR), solution grade styrene butadiene rubber(s-SBR) and Butadiene rubber (BR) for tread and NR/BR for sidewall have been experimented to understand the compatibility with different rubber blend. Microscopic analysis through Scanning electron Microscope (SEM) revealed that the replacement of TRAE oil with MSO does not have any major impact on filler dispersion where physical properties and abrasion resistance is also found unaltered from these studies.
\end{abstract}

Keywords: Dispersion, Green materials, Modified soybean oil (MSO), SEM, Vegetable oil

\section{INTRODUCTION}

Non-renewable petroleum oils are widely used in rubber products to increase the flowability of rubber compound during mixing and processing. Depending on the rubber compound's application, the type of oil used as a plasticizer may affect the processability and physical properties of the compound. Plasticizers are also called as softener, extender or process oil, which are additives for polymers with low molecular weight. It helps to decrease the viscosity of the rubber mixture. With the addition of process oil to polymer matrix the cohesive forces are lowered and chain mobility has increased [1]. These petroleum based oil contains long chain hydrocarbon including several PAHs which is harmful to the environment. Use of process oil containing PAHs viz benzo (a) pyrene (BaP), benzo(e) pyrene (BeP), benzo(a) anthracene (BaA), chrysene (CHR), benzo(b)fluoranthene (BbFA), benzo(j)fluoranthene (BjFA), benzo(k)fluoranthene (BkFA), and dibenzo(a, h)anthracene (DBAhA) restricted by Commission Regulation (EC) No. 552/2009 [2] . In recent years many alternative of safe oils are used in rubber industry like TDAE, MES etc [3]. To minimise carbon foot print of rubber product, renewable resources of vegetable oil was studied as a replacement of petroleum oils as mentioned in the earlier studies $[4,5]$. Plasticizers can be generally classified as mineral oils (petroleum oil, vegetable oil) and other natural products. While choosing plasticizer it is important to optimize the compatibility between oil and elastomers. In this regards non polar plasticizer is preferred to use for non polar elastomers where as polar plasticizers generally used for polar elastomers [6]. From the literature, It was found that in addition to mineral oil vegetable oil can also be used to replace petroleum based product towards sustainable development of rubber compounds [7].

Sustainable development aims at assuring the ongoing productivity of exploitable natural resources and conserving all species of fauna and flora [8]. According to Philip Sutton [9] environmental sustainability can be achieved by reducing usage of physical resources and using more and more renewable rather than depletable resources. To achieve this, redesign of product and process is necessary to avoid toxic material. The tyre industry is raw material intensive it means raw materials account for $65 \%$ of the production cost. Main raw materials for tyre are rubber (natural and synthetic), carbon black, silica, petroleum-based rubber process oil, nylon, polyester, steel cord, bead wire and other rubber chemicals like resins, zinc oxide, stearic acid, sulphur etc. Raw materials used in tyre may be classified into two categories - from non-petroleum origin like natural rubber, silica, steel cord, bead wire. Another raw material class are from petroleum origin like synthetic rubber, carbon black, rubber process oil, synthetic fibres like nylon, polyester [10]. Soybean oil consists of different fatty acids compositions and unsaturation levels, the soybean oil was found to contain 56.6 and 78.9 wt $\%$ of unsaturated fatty acids [11]. Ismail et al [12] studied the effect of fatty acid which is present in palm oil as a vulcanization activator in carbon black filled natural rubber compounds and observed that the cure time along with process safety increased with increased the concentration of fatty acid. Behaviour of fatty acid in natural rubber and synthetic rubber blend has not been performed in this study. 
Dasgupta et.al.[13] analysed the compounds of natural rubber with different types of oil such as naphthenic, aromatic, paraffinic and vegetables oils and observed that the effect of vegetable oil increases the tensile strength.

In the present work, replacement of petroleum based oil with bio based soybean oil in general purpose rubber such as natural rubber (NR), styrene butadiene rubber (SBR) and butadiene rubber (BR) based compounds were investigate with respect to cure characteristics, mechanical and dynamic mechanical properties and ageing retention properties. In addition, an adjustment of vulcanizing agents to improve the rheological properties of compounds containing commercially available modified soybean oil was demonstrated.

\section{EXPERIMENTAL}

\subsection{MATERIALS}

Soybean oil was modified with polyhydric alcohol ( $\mathrm{R}<\mathrm{OH}$ ) (from M/s- Witmans, Daman) and Treated aromatic extract oil (TRAE) (from Raj Petro industries, Chennai) has been used as process oil. Details of other ingredients mentioned in Table 1.

Table 1: Details of ingredients used apart from process

\begin{tabular}{|c|l|l|}
\hline S1 no & \multicolumn{1}{|c|}{ Material } & \multicolumn{1}{c|}{ Supplier } \\
\hline 1 & Ribbed smoked sheet (RSS-4) & Royale rubbers, Guwahati, Assam \\
\hline 2 & Styrene butadiene rubber (NS116) & Reliance Industries limited, Baroda, Gujarat \\
\hline 3 & Poly butadiene rubber (Ni-BR) & Reliance Industries limited, Baroda, Gujarat \\
\hline 4 & 80 mesh crumb rubber & Gujarat reclaim, Ankleshwar, Gujarat \\
\hline 5 & Carbon Black (N339 \& N550) & Birla Carbon, Renukoot, Uttar Pradesh \\
\hline 6 & Silica(VN3) & Speciality Silica, Alwar, Rajasthan \\
\hline 7 & Zinc Oxide (White seal) & Pondy oxide, Puducherry \\
\hline 8 & Stearic acid & 3F Industries,Chennai,Tamilnadu \\
\hline 9 & Microcrystalline Wax & Raj Petro industries, Chennai,Tamilnadu \\
\hline 10 & N,N'-ditolylparaphynylene diamine (DTPD) & Acmechem, Bharuch, Gujrat \\
\hline 11 & $1,2-$ dihydro- 2,2,4-trimethyl quinoline (TMQ) & NOCIL, Thane, Maharastra \\
\hline 12 & MS 40 & Shandong Huatai chemicals Pvt Ltd,Shandong, China \\
\hline 13 & A 60 & Pukhraj Chemicals, Mumbai,Maharastra \\
\hline 14 & PF Resin & Sinolegend chemicals ltd, Zhangiagang,China \\
\hline 15 & N,N'-dicyclohexyl-2-benzothiazole sulfenamide (DCBS) & Acmechem, Panoli, Gujarat \\
\hline 16 & N-tert-butyl-2-benzothiazole sulfenamide (TBBS) & Shandong Huatai Chemicals, Shandong,China \\
\hline 17 & Diphenyl Guanidine (DPG) & Yasho chemicals, Vapi, Gujarat \\
\hline 18 & Prevulcanised Inhibitor (PVI) & NOCIL, Thane, Maharastra \\
\hline 19 & Soluble Sulfur & Jain Chemicals,Kanpur, Uttar pradesh \\
\hline 20 & Insoluble Sulfur (OT20) & OCCL, Mundra,Gujarat \\
\hline
\end{tabular}

\subsection{CHARACTERIAZATION OF MODIFIED SOYBEAN OIL (MSO)}

The modified soybean oil has been characterized as received from supplier. Specific gravity of the modified soybean oil (MSO) has been tested by hydrometer, flash point of the sample tested by automated open cup flash point apparatus (Anton Paar), and kinematic viscosity of the sample tested by ubbelohde viscometer at $100^{\circ} \mathrm{C}$. Results are tabulated in Table 2 .

\subsubsection{CHEMICAL CHARACTERIZATION}

Table 2: Chemical characterization result of MSO

\begin{tabular}{|c|l|l|}
\hline Sl no & \multicolumn{1}{|c|}{ Test } & Result \\
\hline 1 & Specific gravity at $15^{\circ} \mathrm{C}$ & 0.973 \\
\hline 2 & Flash point $\left({ }^{\circ} \mathrm{C}\right)$ & 230.0 \\
\hline 3 & Kinematic viscosity $\left(\mathrm{mm}^{2} / \mathrm{s}\right)$ & 20.33 \\
\hline
\end{tabular}

\subsubsection{CHARACTERISATION BY FTIR}


FTIR study of the sample has been performed (Figure 1) by Spectrum 400, M/S Perkin Elmer. Peak at 3009.63, 2952.81, $2854.80 \mathrm{~cm}^{-1}$ denotes $\mathrm{C}-\mathrm{H}$ stretching, peak at $1746.00 \mathrm{~cm}^{-1}$ confirms the presence of $>\mathrm{C}=\mathrm{O}$ functional group, peak at $1464,1377,722.94 \mathrm{~cm}^{-1}$ denotes $\mathrm{C}-\mathrm{H}$ bending and $1238.25,1163.55,1120.13 \mathrm{~cm}^{-1}$ peaks denotes for $\mathrm{C}-\mathrm{O}-\mathrm{C}$ bond stretching.

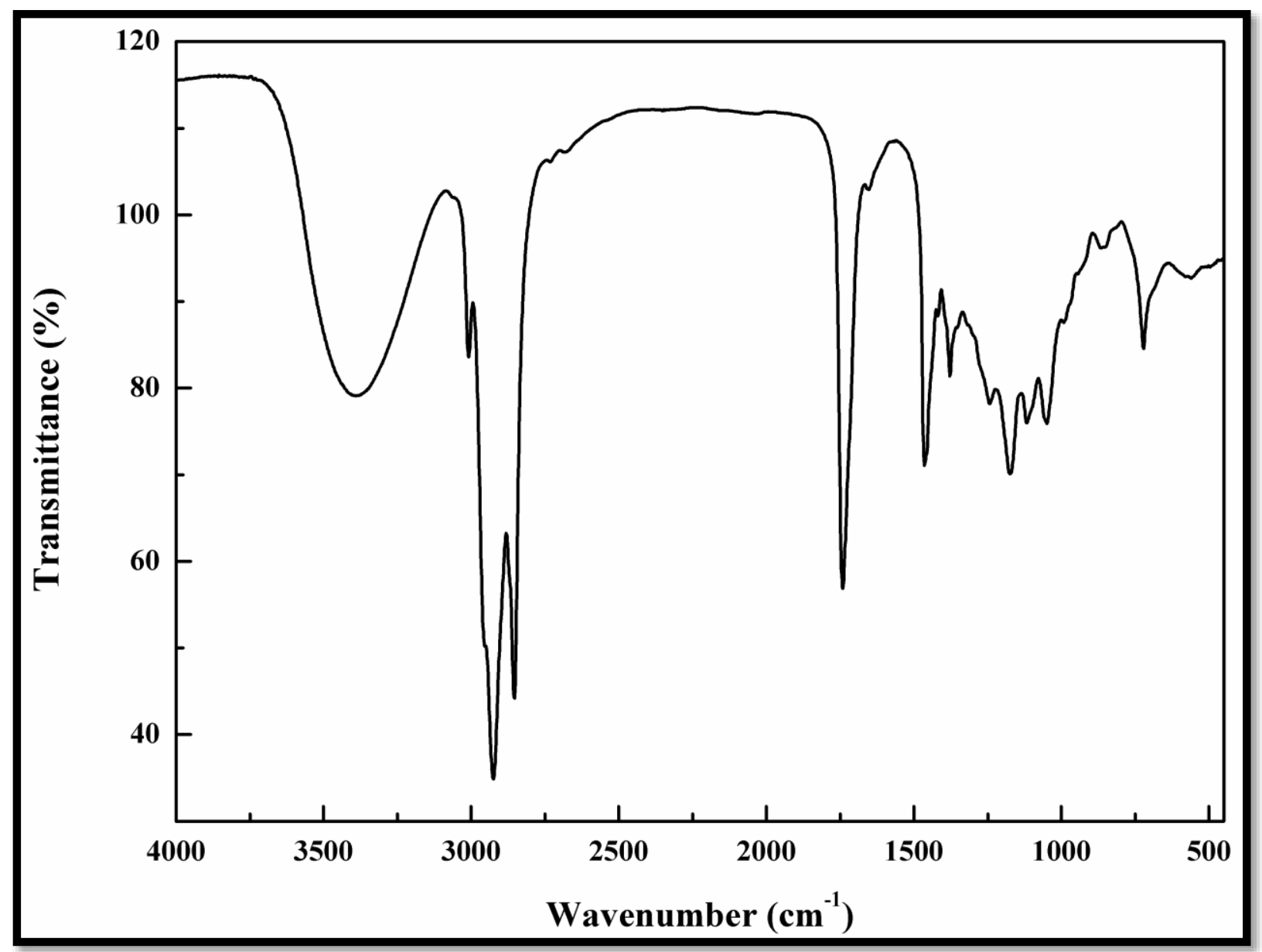

Figure 1: FTIR spectra of soybean oil

Glass transition and thermal degradation study of the MSO has been performed by Differential scanning calorimeter (TA instrument) and Thermogravimetric analyser (Perkin Elmer). Glass transition temperature of the sample is $(-) 53.12^{\circ} \mathrm{C}$ (Figure $2 \mathrm{a}$ ) and the degradation peak found at $388.7^{\circ} \mathrm{C}$ (Figure $2 b$ ).

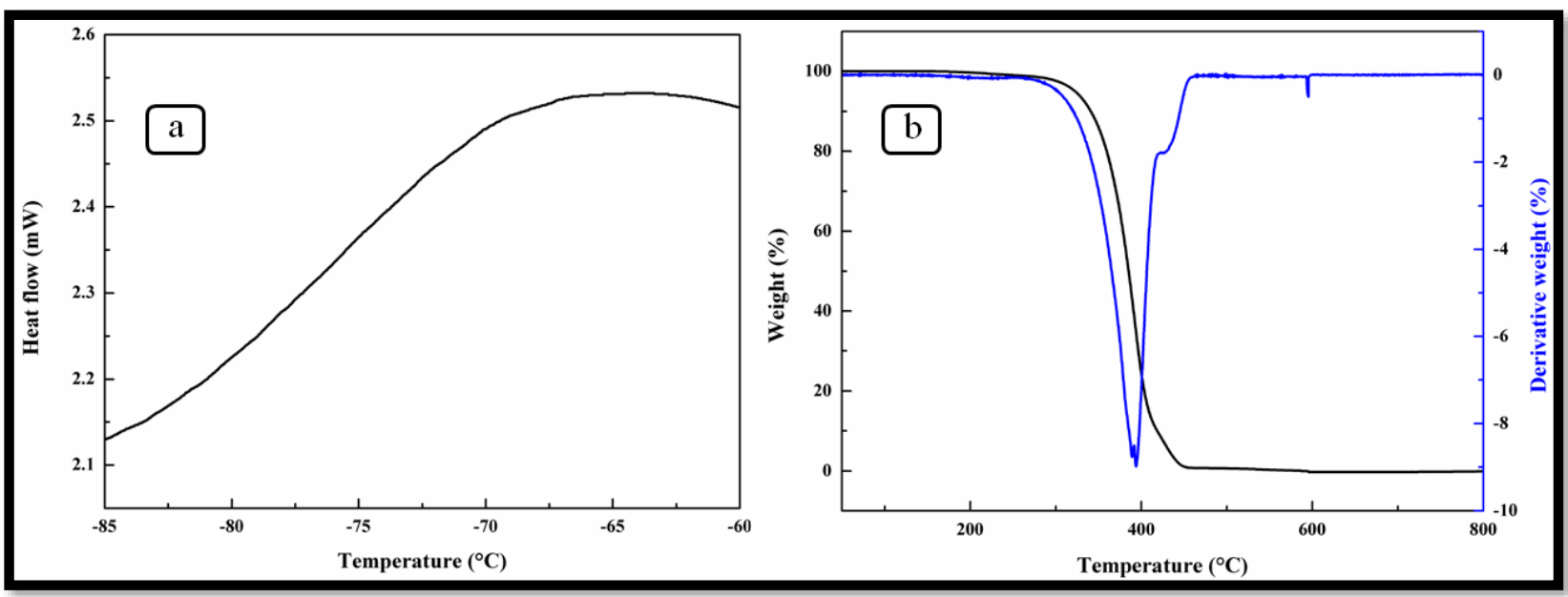

Figure 2: Glass transition temperature (a) and thermal degradation (b) of Soybean oil 


\section{PREPARATION OF RUBBER COMPOUNDS}

In passenger car radial (PCR) compound segment we have used above mention ingredients for mixing and have chosen two different compounds for our study. We have taken PCR tread and Sidewall (SW) compound for our study. Mixing has done in accordance with ISO 2393 in tangential mixer (Stewart bolling Banbury, volume 1.6L, Hudson, OH, USA) with fill factor 0.75.The tread compounding formulation and mixing procedure has shown below Table 3,4.

Table 3: Formulation of tread compound

\begin{tabular}{|c|c|c|c|}
\hline Ingredients & Tread Control, Phr & Tread MSO1,Phr & Tread MSO2,Phr \\
\hline NR & 25 & 25 & 40 \\
\hline SSBR & 40 & 40 & 35 \\
\hline PBR & 35 & 35 & 60 \\
\hline N339 & 58 & 58 & - \\
\hline TRAE Oil & 20 & -20 & 46 \\
\hline MSO & - & 4 & 2.25 \\
\hline Silica & 4 & 2.25 & 0.5 \\
\hline ZnO & 2.25 & 0.5 & 1.5 \\
\hline St. acid & 0.5 & 1.5 & 1.5 \\
\hline 6PPD & 1.5 & 1.5 & 0.5 \\
\hline McWAX & 1.5 & 0.5 & 1 \\
\hline DTPD & 0.5 & 1 & 2 \\
\hline MS40 & 1 & 2 & 0.4 \\
\hline SULFUR & 2 & 0.4 & 1.1 \\
\hline DCBS & 0.4 & 1.1 & 0 \\
\hline TBBS & 1.1 & 0.2 & 0.2 \\
\hline DPG & 0.2 & 0.15 & \\
\hline PVI & 0.15 & & \\
\hline & & & \\
\hline
\end{tabular}

Initial mixer temperature was $73 \pm 3^{\circ} \mathrm{C}$ and rotor speed $60 \pm 3 \mathrm{rpm}$. The compound was mixed in a three stage like master, repass and final. In master stage polymer, filler, oil and antidegradant were used. In repass stage compound is mixed with initial temperature $65^{\circ} \mathrm{C}$ to $70^{\circ} \mathrm{C}$ and rotor speed 45 .In final stage of mixing all curatives were put in to the banbury with same temperature as above mentioned with rotor speed 30rpm. In all three cases (master, repass and final) dump temperature maintained $140^{\circ} \mathrm{C}$ to $145^{\circ} \mathrm{C}, 125^{\circ} \mathrm{C}$ to $130^{\circ} \mathrm{C}$ and $90^{\circ} \mathrm{C}$ to $95^{\circ} \mathrm{C}$. Mixing sequence as mentioned in Figure 3 . 


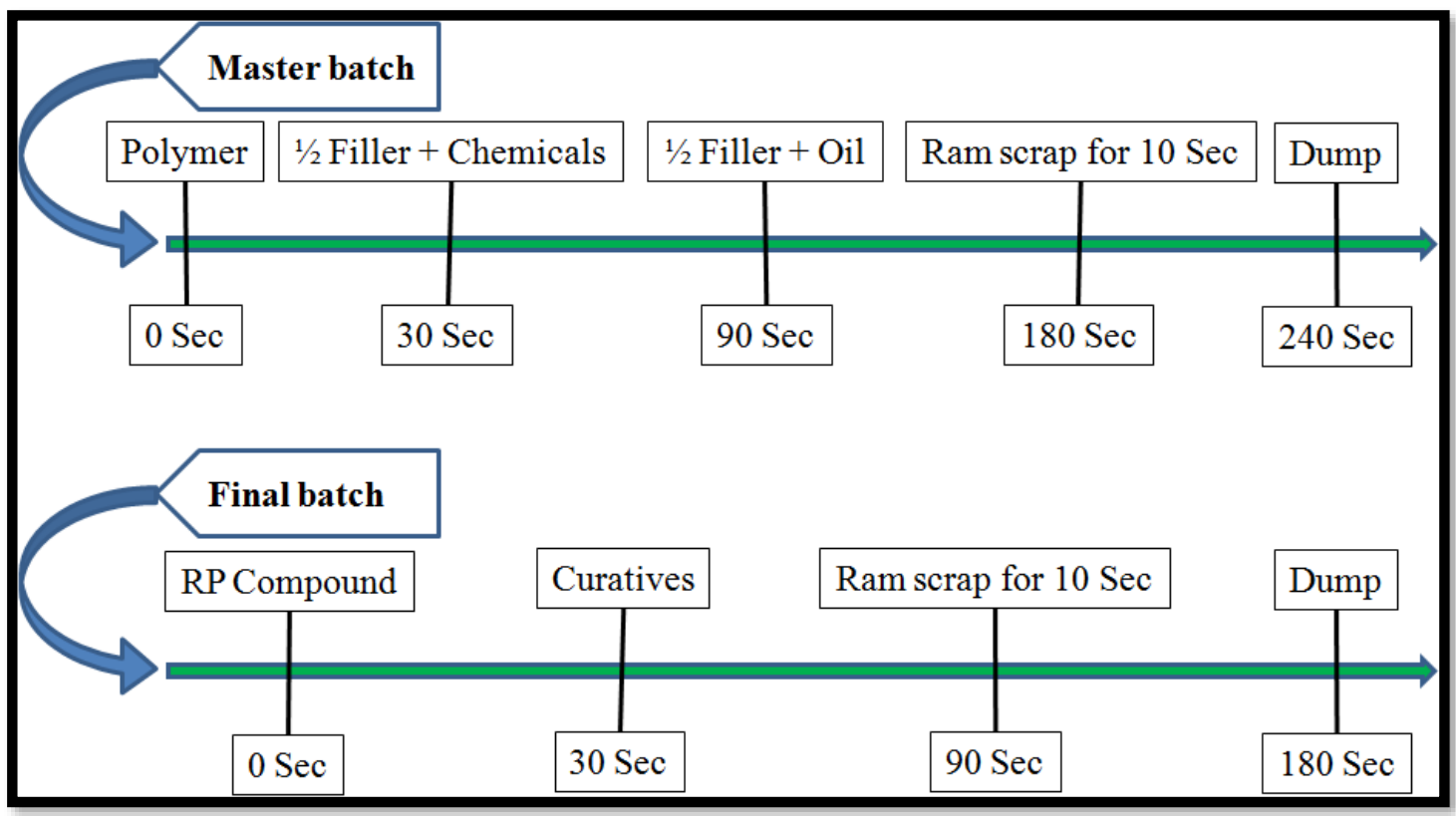

Figure 3: Mixing sequence of master and final batches for tread and SW compound

We have taken a trial in Sidewall (SW) compound and the compound formulation is mentioned in Table 4 as well as mixing sequence is followed as above mentioned in Figure 3.

Table 4: Formulation of sidewall compound

\begin{tabular}{|c|c|c|c|}
\hline Ingredients & SW Control, Phr & SW MSO1,Phr & SW MSO2,Phr \\
\hline NR & 50 & 50 & 50 \\
\hline PBR & 50 & 50 & 50 \\
\hline N550 & 55 & 55 & 57 \\
\hline TRAE Oil & 7 & - & 6 \\
\hline MSO & - & 7 & 3.5 \\
\hline ZnO & 3.5 & 3.5 & 2.5 \\
\hline St Acid & 2.5 & 2.5 & 3.5 \\
\hline 6PPD & 3.5 & 3.5 & 4 \\
\hline PF Resin & 4 & 4 & 3.5 \\
\hline KO Resin & 1.5 & 1.5 & 2 \\
\hline 80 Mesh & 3 & 3 & 0.5 \\
\hline MC Wax & 2 & 2 & 0.82 \\
\hline DPPD & 0.5 & 0.5 & 1.03 \\
\hline SULFUR & 0.82 & 0.82 & 0.4 \\
\hline Ins S & 1.03 & 1.03 & 0.4 \\
\hline DCBS & 0.4 & 0.4 & 0.5 \\
\hline TBBS & 0.4 & 0.4 & 0.3 \\
\hline TMQ & 0.5 & 0.5 & 0.2 \\
\hline PVI & 0.2 & & 3 \\
\hline
\end{tabular}

The SW compound is mixed in two stages, master and final and had controlled the temperature in master $135^{\circ} \mathrm{C}$ to $140^{\circ} \mathrm{C}$ and final $90^{\circ} \mathrm{C}$ to $95^{\circ} \mathrm{C}$ with 60rpm and 30rpm rotor speed. 
In both formulations we have taken the trial with same dosage of oil and other ingredients and also adjusted the dosages of oil and PVI because to adjust the cure properties of control and MSO2 mixed compound. In tread compound we have eliminated the DPG from control compound in MSO2 compound.

\subsection{RHELOGICAL PROPERTIES}

3.1.1. Viscosity: Mooney viscosity of the rubber compounds were tested by using Mooney viscometer (MV2000,Alpha technologies, Akron, USA, ASTM D1649) and complex viscosity of tyre tread compound were tested by rubber process analyser (RPA2000, Alpha technologies, Akron, USA) at $100^{\circ} \mathrm{C}$ and $2.79 \%$ strain with varying frequency sweeps ( $2 \mathrm{~Hz}$ to $32 \mathrm{~Hz}$ ).

3.1.2. Process safety: Mooney scorch of the rubber compound is well known as process safety, tested by using Mooney viscometer (MV2000, Alpha technologies, Akron, USA, ASTM D1649).

3.1.3. Payne effect: The storage moduli (G') of the rubber compounds with curatives was evaluated by using RPA 2000, Alpha technologies, Akron, USA under a temperature of $100^{\circ} \mathrm{C}$, frequency of $0.5 \mathrm{~Hz}$ and varying strains in the range $0.1 \%$ to $100 \%$. The Payne effect was calculated from the difference in storage moduli at low strain $(0.1 \%)$ and high strain $(100 \%)$.

\subsection{PHYSICAL PROPERTIES}

3.2.1. Cure behavior: Cure time and cure torques were tested in Premier MDR2000, Alpha technologies, Akron, USA at $160^{\circ} \mathrm{C}$ for all compounds. The cure index (CRI) was calculated as [100/(tc90-ts2)].

3.2.2. Tensile tests: The compounds were vulcanised to their optimum cure time (tc90) with 1.5 times by using a Hind hydraulic laboratory curing press at $160^{\circ} \mathrm{C}$ and $150 \mathrm{Kg} / \mathrm{cm}^{2}$. Die $\mathrm{C}$ dumbbell test specimen were prepared and then tensile properties (i.e, modulus, tensile strength, elongation at break) were tested at Zwick tensile tester model Z010 (Zwick Roell group,Ulm, Germany) at a cross head speed $500 \mathrm{~mm} / \mathrm{min}$ according to ASTM D412. Dumbbell hardness test was carried out in Durometer hardness tester according to ASTM D2240.

3.2.3. Rebound Resilience tests: The compounds were vulcanised by using hind hydraulic laboratory curing press at $141^{\circ} \mathrm{C}$ and $150 \mathrm{Kg} / \mathrm{cm}^{2}$. Test specimen (cured button) were tested at Zwick GmbH, Ulm, Germany (ISO4662) at $23^{\circ} \mathrm{C}$ and $70^{\circ} \mathrm{C}$.

3.2.4. Abrasion test: The compound were vulcanised by using hydraulic laboratory curing press at $141^{\circ} \mathrm{C}$ and $150 \mathrm{Kg} / \mathrm{cm}^{2} . \mathrm{Test}$ specimen (cured button) were tested at DIN abrader, Braseiss, Germany (ISO4649). The specimens were tested at 5N load and drum speed 40rpm and roll diameter was 150 X $450 \mathrm{~mm}$.

3.2.5. Dynamic Mechanical Properties by Dynamic Mechanical Analyser: The dynamic mechanical properties of the rubber compound characterised with a dynamic mechanical analyser (DMA+2000, Metravib, France). The samples were cut into 24 X 10 X 2 $\mathrm{mm}^{3}$ specimens and tested in tension compression mode with a stabilized temperature $0^{\circ} \mathrm{C}, 30^{\circ} \mathrm{C}$ and $70^{\circ} \mathrm{C}$ at frequency of $10 \mathrm{~Hz}$ and $0.1 \%$ dynamic strain.

3.2.6. Ageing test: Ageing test of tensile dumbbell done at $105^{\circ} \mathrm{C}$ for $48 \mathrm{~h}$ for tread and $\mathrm{SW}$ compound. The equipment is used for this ageing study is Multi cell ageing oven, Tempo Industries, Bengaluru, India. Ageing was performed in presence of Oxygen so it is called aerobic ageing.

3.2.7. Wear analysis by LAT100: Abrasion test of test specimen done at $25^{\circ} \mathrm{C}$ for $20 \mathrm{~km} / \mathrm{h}$ with same load $40 \mathrm{~N}$ and different slip angle $\left(1^{\circ}\right.$ and $\left.2^{\circ}\right)$. The equipment is used for this test is Laboratory Abrasion tester,VMI, Holand.

3.2.8. Material mapping by SEM-EDS: Material mapping done at RT for test specimens. The equipment is used for this study is Thermofisher, Dreieich, Germany.

\subsection{PROCESSING BEHAVIOUR}

3.3.1. Garvey Die Extrusion test: The compound extruded through HAAKE rheomix, Thermofisher, Dreieich Germany. The temperature of extrusion was maintained at $80 \pm 2{ }^{\circ} \mathrm{C}$ and screw speed $40 \pm 3 \mathrm{rpm}$. Garvey die orifice $10 \mathrm{~mm}$. Measure the initial length of the profile in $\mathrm{mm}$ and take the reading after $24 \mathrm{~h}$ up to $72 \mathrm{~h}$. By that way we can measure the shrinkage of the compound in percentage. 


\section{RESULTS AND DISCUSSION}

\subsection{RHELOGICAL PROPERTIES}

The dump temperature in the first stage of tread compounds was aimed to $140^{\circ} \mathrm{C}$ to $145^{\circ} \mathrm{C}$ where as other compounds were dumped at $135^{\circ} \mathrm{C}$ to $140^{\circ} \mathrm{C}$. The use of TRAE oil and MSO2 results for tread compound is very similar with respect to viscosity, scorch safety, torque and cure time (Table 5).

Table 5: Rheological properties, Mooney viscosity and Scorch for tread and SW compound

\begin{tabular}{|c|c|c|c|c|c|c|}
\hline Property & $\begin{array}{c}\text { Tread } \\
\text { Control }\end{array}$ & $\begin{array}{c}\text { Tread } \\
\text { MSO1 }\end{array}$ & $\begin{array}{c}\text { Tread } \\
\text { MSO2 }\end{array}$ & $\begin{array}{c}\text { SW } \\
\text { Control }\end{array}$ & $\begin{array}{c}\text { SW } \\
\text { MSO1 }\end{array}$ & SW MSO2 \\
\hline ML(1+4)@ $100^{\circ} \mathrm{C}, \mathrm{MU}$ & 61 & 56 & 66 & 53 & 52 & 53 \\
\hline Scorch time (t5), min & 14 & 8.6 & 13.2 & 14.3 & 16.1 & 16.1 \\
\hline Minimum torque, lb-in & 1.96 & 2.12 & 2.39 & 2.11 & 1.93 & 2.24 \\
\hline Maximum torque, lb-in & 13.91 & 15.98 & 14.75 & 10.18 & 10.03 & 10.18 \\
\hline ts2, min & 4.08 & 4.03 & 3.93 & 5.26 & 4.79 & 5.13 \\
\hline Cure time, tc90, min & 7.56 & 6.08 & 8.01 & 10.54 & 9.19 & 10.29 \\
\hline Cure rate index, $\min ^{-1}$ & 28.74 & 48.78 & 24.51 & 18.94 & 22.72 & 19.38 \\
\hline
\end{tabular}

The use of TRAE oil and MSO2 results for SW compound is also showing very similar with respect to viscosity, torque and cure time with better process safety.

The cure properties of the tread compound (MSO2) have shown identical behaviour (Table 5). The ultimate curing is comparable for both compounds (MSO2 and Control). In such process safety or scorch is comparable for MSO2 and control compounds, minimum torque and maximum torque is also shown that MSO2 and control compounds has same cross linking. And it will help to achieve the same reinforcement in the compounds. But MSO1 for tread compound has shown low Mooney viscosity and Scorch, this is due to presence of lots of unsaturated fatty acid which also impact in the optimum cure (tc90) and faster cure behaviour is observed.

On the other hand for SW compound has shown little fast curing without hampering the process safety. The cure properties of SW compound have shown in Table 5. In SW MSO1 compound is showing comparable Mooney viscosity and high torque value which indicates that high cross linking in to the rubber matrix. Probably this is due to interaction between poly butadiene moieties with long chain fatty acid [14]. But in case of MSO2 compound scorch safety is better due to concentration of fatty acid increases; the same thing was described by Ismail et. al. with palm oil [12].

Maximum torque is observed little lower for MSO2 compound (Table 5) has denoted little less cross linking, may it will give little low reinforcement $[15,16]$. The Payne effect study for MSO1 of both tread and SW compound has not done because of the test result is not good enough for further study. Very low process safety is not recommended for plant trial.

\subsection{MOONEY STRESS RELAXATION PROPERTIES}

Mooney viscosity stress relaxation for tread and SW compounds are given below in Figure 6a and b. 

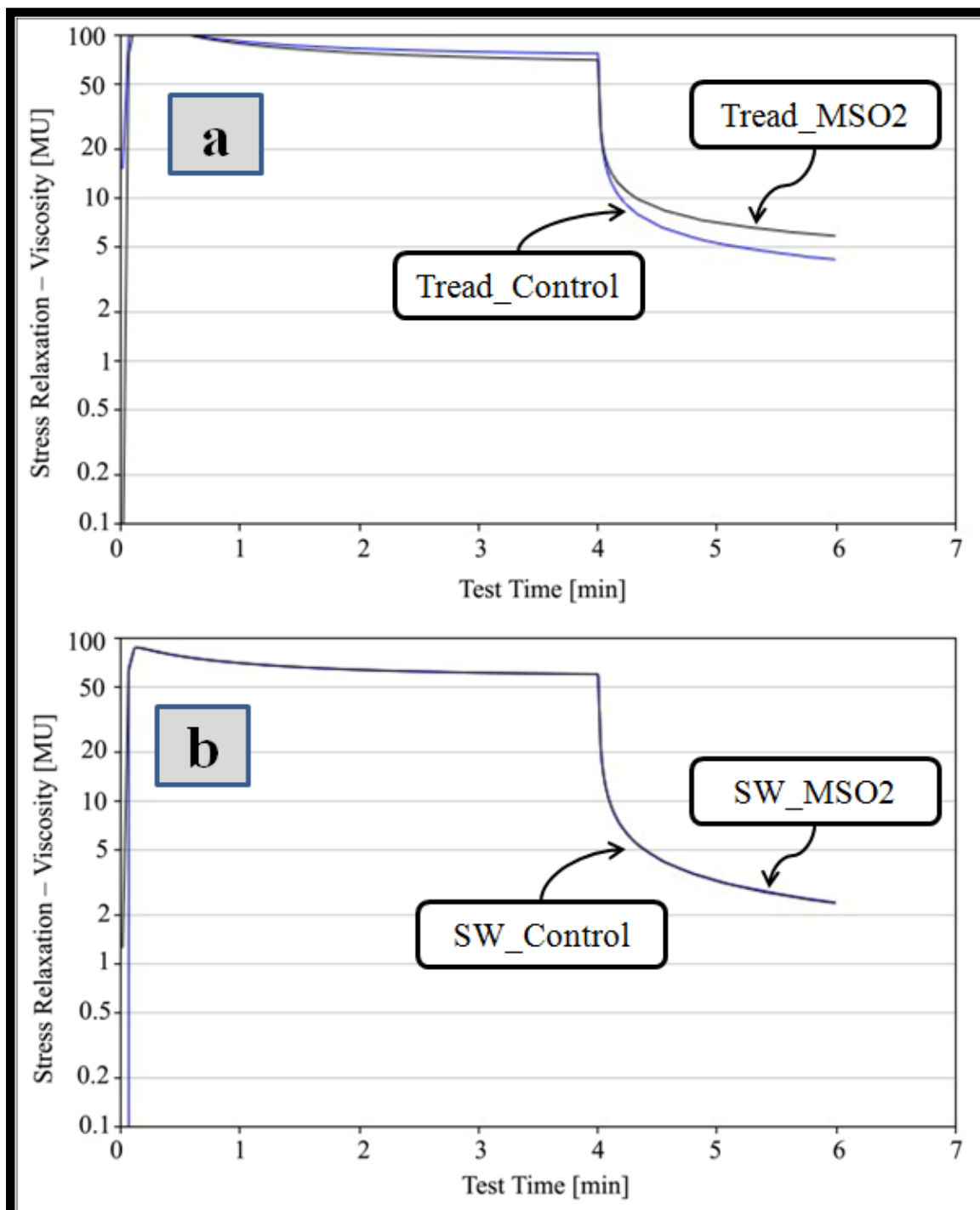

Figure 4: Stress relaxation with respect to time for (a) tread compound and (b) SW compound

For Mooney stress relaxation test if the rotor is suddenly stopped then the stress of the sample attenuates .The stress relaxation test determines the attenuation rate of the torque as a function of time. The relaxation of stress in rubber materials tends to depend on a combination of viscous and elastic component of unvulcanised rubber. Now it has been seen that in Figure 4a, for tread control compound has fast relaxation after stopping the rotor, which indicates that higher level of viscous component present in the compound [17]. Whereas MSO2 compound has delayed relaxation compared to control compound that indicates higher level of elastic component present in compound. The unvulcanised rubber of control compound has more molecular chain entanglement which indicates the more viscous component in compounded rubber.

But for SW compound it has been observed that two graphs are completely identical (Figure 4b). This is only because of both the compounds have identical molecular weight distribution in molecular chains.

\subsection{PAYNE EFFECT}

The Payne effect study has been done in RPA (Figure 5) under different strain $0.1 \%$ to $100 \%$. In this study we have observed that at low strain the storage moduli (G') is low for MSO2 mixed compound and by this reason filler - filler interaction becomes weaker and got a good 'Payne effect' value $\left(\Delta G\right.$ ', 1.82) where as for control compound $\left(\Delta G^{\prime}, 2.00\right)$. That also indicates good dispersion of filler in rubber matrix. 


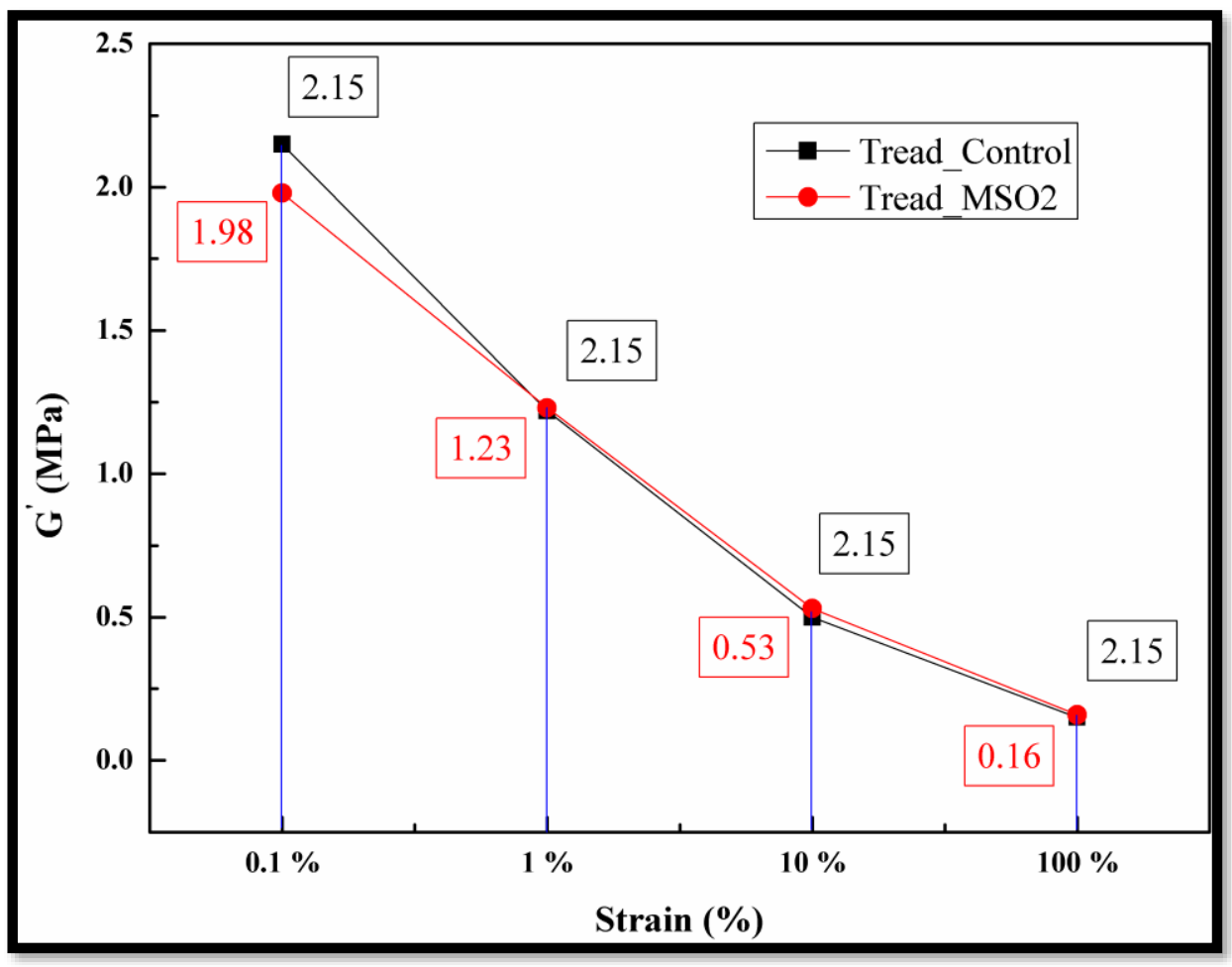

Figure 5: Payne effect as a function of strain sweep for tread compound

\subsection{FREQUENCY SWEEP}

The complex viscosities (Figure 6a) of tread compound (MSO2) shows significant differences, especially at low frequency. At higher frequency both the compounds has shown same complex viscosity (n). The rubber compounds with MSO2 have shown the low complex viscosity which indicates the flow ability is more for this oil. That facilitates the filler incorporation and dispersion in rubber matrix.

Whereas the complex viscosity (Figure 6b) of SW compound (MSO2) has shown marginally differences at low frequency (2Hz) but it is identical at high frequencies, which indicates that the plasticizing effect of bio oil is same for control and MSO2 compound [18]. 


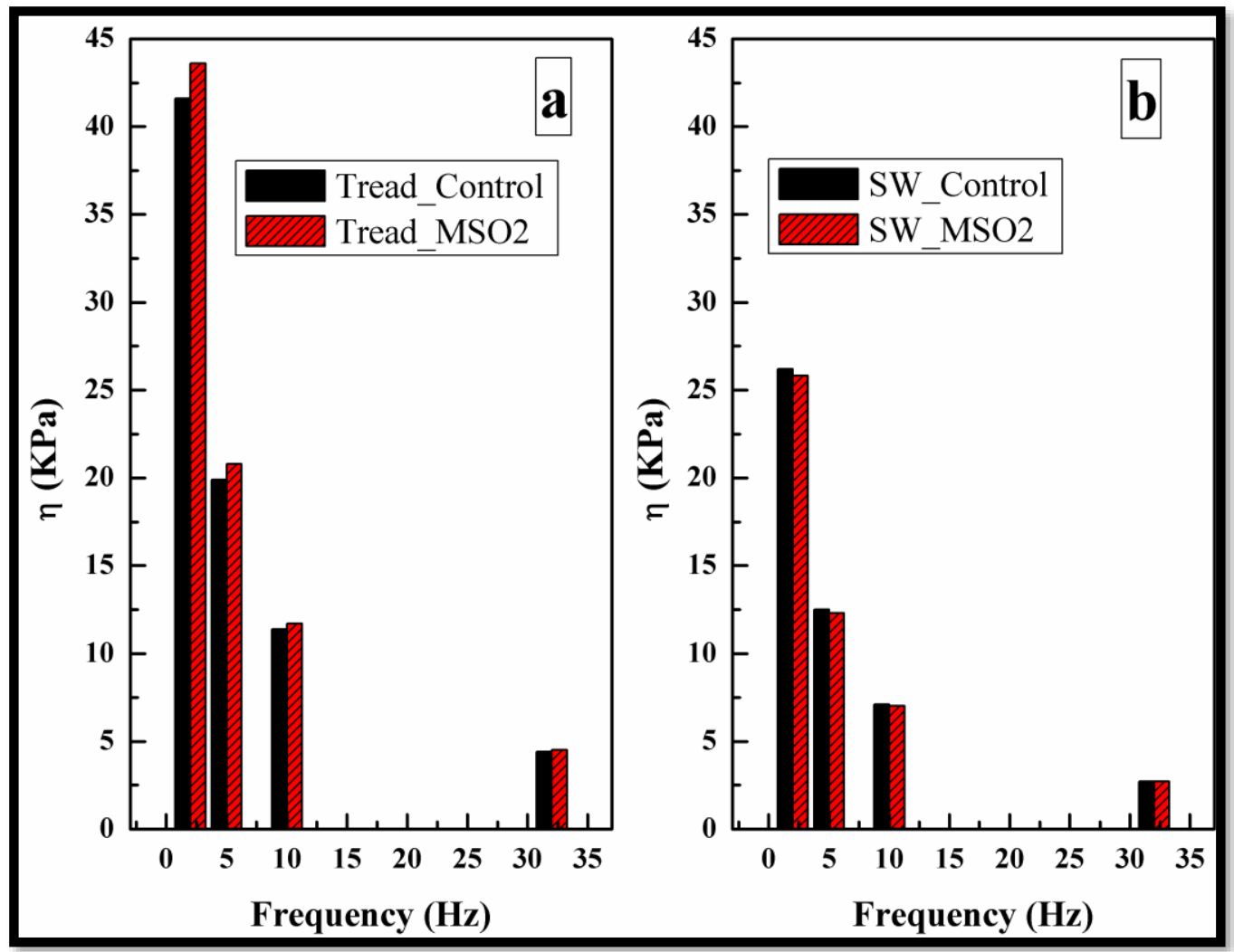

Figure 6: Complex viscosity as a function of frequency sweep for (a) Tread compound and (b) SW compound

\subsection{PROCESSABILITY BY GARVEY DIE EXTRUSION}

The garvey die extrusion image is shown in Figure 7 a,b, in which the role of oil is to flow of the compounds in extruder. That signifies that less the viscous component more the flow ability, and better processing under stress condition. So processing will be better for MSO2 mixed compound. From, Figure 4 it has been proven that in stress relaxation testing the viscous component is more for control compound so it has less flow ability at extruder than MSO2 compound. However both the compounds have shown similar edge tearing and shrinkage behaviour with better surface finish (Table 6)

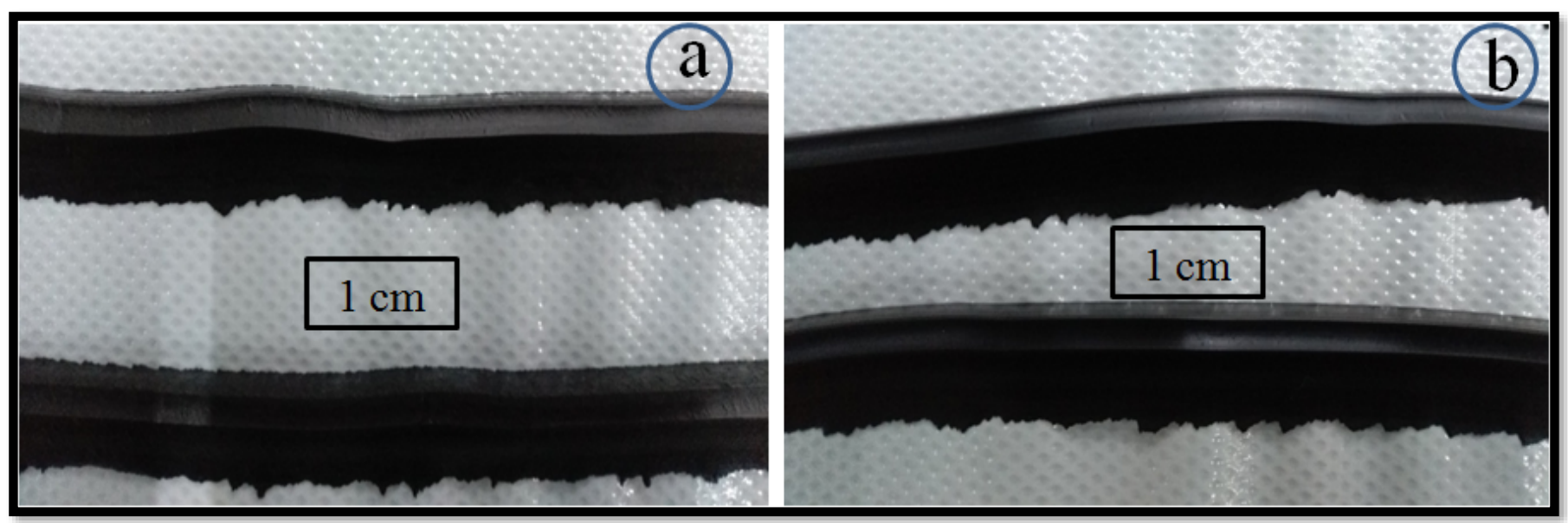

Figure 7: Garvey die extrusion image for (a) tread control(top) \& tread MSO2(bottom) compound and (b) SW control(top) \& SW MSO2(bottom) compound

Table 6: Shrinkage study of tread and SW compound 


\begin{tabular}{|c|c|c|c|c|}
\hline Property & Tread Control & $\begin{array}{c}\text { Tread } \\
\text { MSO2 }\end{array}$ & SW Control & SW MSO2 \\
\hline Shrinkage after 24 h (\%) & 1.3 & 1.2 & 2.3 & 2.2 \\
\hline Shrinkage after 48 h (\%) & 0.6 & 0.6 & 1.5 & 1.4 \\
\hline Shrinkage after 72 $\mathrm{h}(\%)$ & 0.1 & 0.1 & 0.3 & 0.3 \\
\hline
\end{tabular}

\subsection{DISPERSION STUDY BY SEM}

The dispersion of filler into rubber matrix has been carried out by SEM, which indicates that filler particles are uniformly distributed throughout the matrix. Magnification of images were fixed at 5000X and 20000X for all the compounds. No significant changes were found in terms of morphological appearance which is also an indication of comparable dispersion for both the compounds as Tread and SW. It can be said that interaction between filler and polymer is almost similar to the reference one or even better for MSO2 compound for both the components. Representative images have been summarized in Figure 8. 


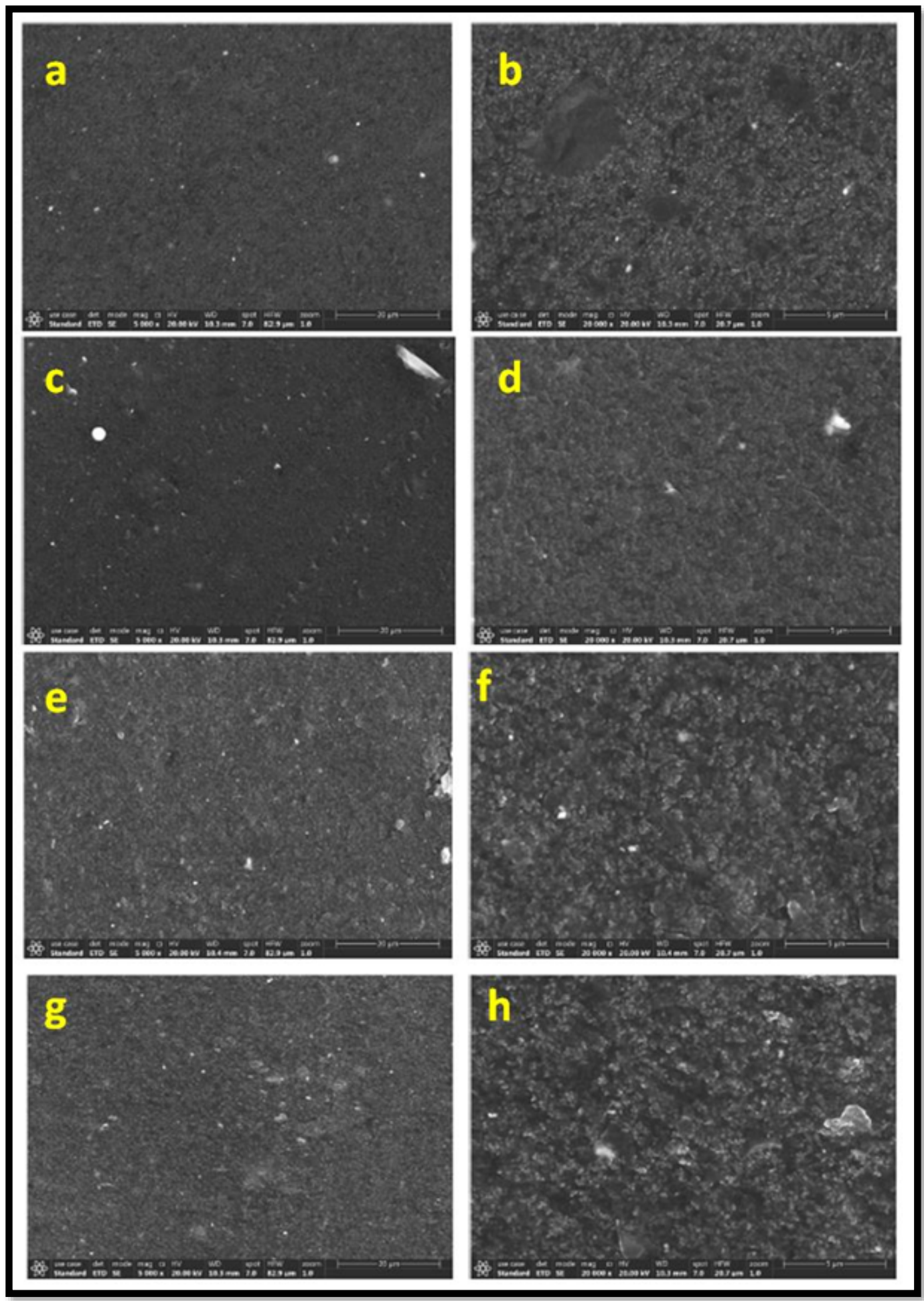

Figure 8: Representative images of dispersion study through SEM at 5000X and 20000X for $(a, b)$ Tread compound with TRAE oil, $(\mathrm{c}, \mathrm{d})$ modified Soybean oil, $(\mathrm{e}, \mathrm{f})$ for Sidewall compound with TRAE oil and $(\mathrm{g}, \mathrm{h})$ for soybean oil

\subsection{PHYSICAL PROPERTIES}

The stress-strain properties of rubber vulcanizates with TRAE oil, MSO1 and MSO2 are tabulated in Figure 9. 


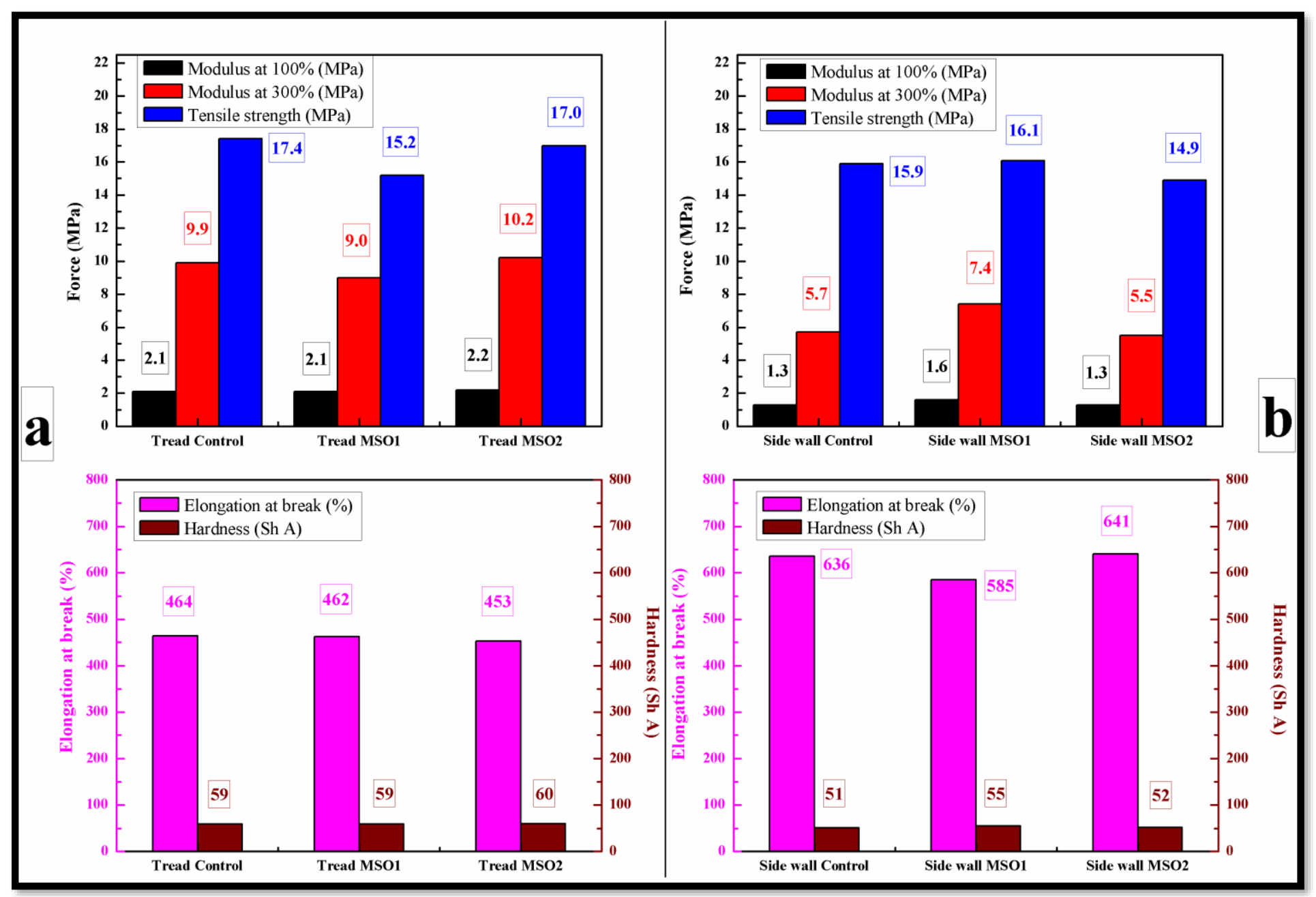

Figure 9: Stress-strain properties of (a) Tread Compound and (b) SW compound

TRAE oil mixed tread compound has shown little lower modulus with respect to MSO2 mixed compound. Tensile strength and elongation at break of the control compound has higher value than the other one. It depends on many factors such as filler rubber interaction, filler filler interaction properties of the rubber compound and network formation of sulfur/accelerator into rubber matrix. Even though the filler interaction or Payne effect is low for MSO2 mixed compound but its highest temperature and shear force during mixing could damage the polymer chains of rubber molecules or degradation [19].MSO1 compound has shown less static stiffness up to $300 \%$ elongation of the rubber composites due to it would have same phenomena [20]. In both the cases we got the same hardness value which indicates no local deformation happened into the rubber matrix.

Among all SW compounds, MSO1 is found to be higher modulus (100\% and 300\%) due to oil lubricates the rubber chains while mixing, causing less chain break down and thus the amine group of accelerator promotes cure to result in higher network structure. While the other compound MSO2 lubrication is being decreased and chain breakdown is observed that's what got the low reinforcement and tensile strength [21].

As MSO2 compound showed superior rheological and physical properties in comparison to the MSO1, So further studies have been carried out only with MSO2 compound for both tread and sidewall application.

\subsection{AGED PHYSICAL PROPERTIES.-}

The ageing retention properties (\%) of TRAE oil mixed and MSO2 mixed compound vulcanizates has shown in Figure 10. 


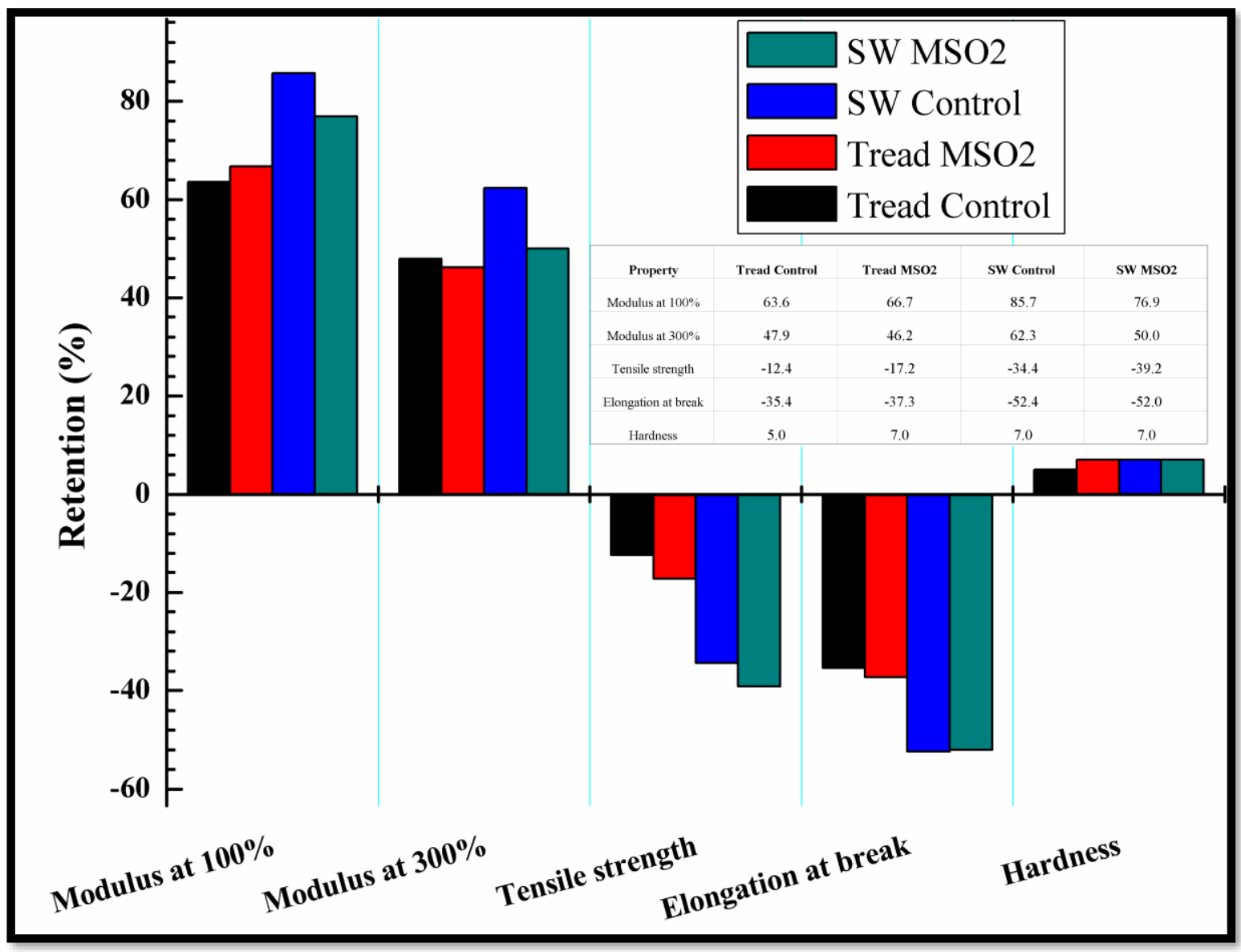

Figure10: Stress strain properties of tread and SW compound after ageing

The ageing retention properties (Modulus 100\% and 300\%) of MSO2 tread compound have comparable with control compound. It indicates that polymer chains with S-S linkages are not damaged under heat treatment in presence oxygen.

On the other side ageing retention properties of $\mathrm{MSO} 2 \mathrm{SW}$ compound has shown some better performance with respect to control. It might be able to for better reinforcement of this compound so at flexing condition S-S bond will not damage and we shall get better performance by using soybean oil in SW compound.

\subsection{REBOUND RESILENCE PROPERTIES}

Rebound resilience properties in terms of hysteresis loss of both the compounds (tread and SW) are comparable or could say little deformation is observed for MSO2 mixed compound due to presence of long chain fatty acid in MSO2. Rebound resilience, percentage is measure in the test is inversely proportional to hysteresis loss. The wear properties are also better for $\mathrm{MSO} 2$ mixed compound or low volume loss is observed during abrasion test. Rebound resilience at $23^{\circ} \mathrm{C}$ indicates the traction property of the compound, higher the value indicates higher grip property. In both the cases it has been observed that rebound resilience is comparable not it will not impact in dry traction property of the compound. Comparable rebound resilience at $70^{\circ} \mathrm{C}$ indicates without sacrifice in rolling resistance (hysteresis loss) property in both the cases. The properties have shown in Table 7.

Table 7: Rebound resilience properties of tread and SW compound

\begin{tabular}{|c|c|c|c|c|}
\hline Property & Tread Control & Tread MSO2 & SW Control & SW MSO2 \\
\hline Rebound resilience, $23^{\circ} \mathrm{C}$ & 44.6 & 42.7 & 51.7 & 50.6 \\
\hline Rebound resilience, $70^{\circ} \mathrm{C}$ & 57.7 & 56.0 & 60.6 & 59.7 \\
\hline
\end{tabular}


The dynamic mechanical properties in terms of change of storage modulus (E') and loss tangent or tan $\delta$ with temperature of both the compound are shown in Table 8.

Table 8: Dynamic properties of tread and SW compound

\begin{tabular}{|c|c|c|c|c|}
\hline Property & Tread Control & Tread MSO2 & SW Control & SW MSO2 \\
\hline $\tan \delta$ at $0^{\circ} \mathrm{C}$ & 0.302 & 0.309 & 0.217 & 0.262 \\
\hline $\tan \delta$ at $30^{\circ} \mathrm{C}$ & 0.263 & 0.274 & 0.196 & 0.239 \\
\hline $\tan \delta$ at $70^{\circ} \mathrm{C}$ & 0.208 & 0.207 & 0.168 & 0.178 \\
\hline $\mathrm{E}^{\prime}$ at $0^{\circ} \mathrm{C}, \mathrm{MPa}$ & 13.6 & 14.3 & 7.73 & 8.86 \\
\hline $\mathrm{E}^{\prime}$ at $30^{\circ} \mathrm{C}, \mathrm{MPa}$ & 10.1 & 10.2 & 6.17 & 6.55 \\
\hline $\mathrm{E}^{\prime}$ at $70^{\circ} \mathrm{C}, \mathrm{MPa}$ & 7.75 & 7.5 & 4.41 & 4.54 \\
\hline
\end{tabular}

Compound with MSO2 for tread shows comparable loss tangent thorough out the temperature like $0^{\circ} \mathrm{C}, 30^{\circ} \mathrm{C}$ and $70^{\circ} \mathrm{C}(\mathrm{Table} 7)$. The $\tan \delta$ values of rubber compound indicate the elastic behaviour of vulcanizates. The tan $\delta$ value at $0^{\circ} \mathrm{C}$ of $\mathrm{MSO} 2$ compound shows higher value which indicates poor elastic property or higher damping at this temperature and the similar phenomenon is observed at $30^{\circ} \mathrm{C}$ and $70^{\circ} \mathrm{C}$. For tyre application, tan $\delta$ at $0^{\circ} \mathrm{C}$ indicates wet grip, $30^{\circ} \mathrm{C}$ indicates dry grip and at $70^{\circ} \mathrm{C}$ indicates rolling resistance [22]. Based on Table 7, the presence of MSO2 for tread compound does not create any significant change in wet grip, dry grip and slightly lower the rolling resistance (i.e, lower tan $\delta$ at $70^{\circ} \mathrm{C}$ ). The stiffness value of MSO2 compound is very similar with TRAE compound which indicates dynamic moduli will not be compromised at stress condition. Dynamic mechanical value conforming that replacement of TRAE oil by MSO2 will not affect the tyre performance or properties and it improves the rolling resistance with not a sacrifice of grip and wears properties.

The dynamic properties of MSO2 compound for SW is attributed that at $0^{\circ} \mathrm{C}, 30^{\circ} \mathrm{C}$ and $70^{\circ} \mathrm{C}$ the storage modulus value (i.e, higher crosslink) is high. Throughout the $\tan \delta$ value is significantly high for MSO2 which executes the good wet grip (tan $\delta$ at $0^{\circ} \mathrm{C}$ ), dry grip $\left(\tan \delta\right.$ at $30^{\circ} \mathrm{C}$ ) of compound (Table 6); the probable reason for slightly higher compound rolling resistance (tan $\delta$ at $70^{\circ} \mathrm{C}$ ) is due to decrease of oil dosage executes lower plasticizing effect in compound so that increases of viscous moduli (E") is more than storage moduli (E') of vulcanizates [23].

\subsection{WEAR PROPERTIES}

The Abrasion loss and abradability were tested in Laboratory Abrasion Tester (LAT 100), the properties has been given below in Figure 11. 


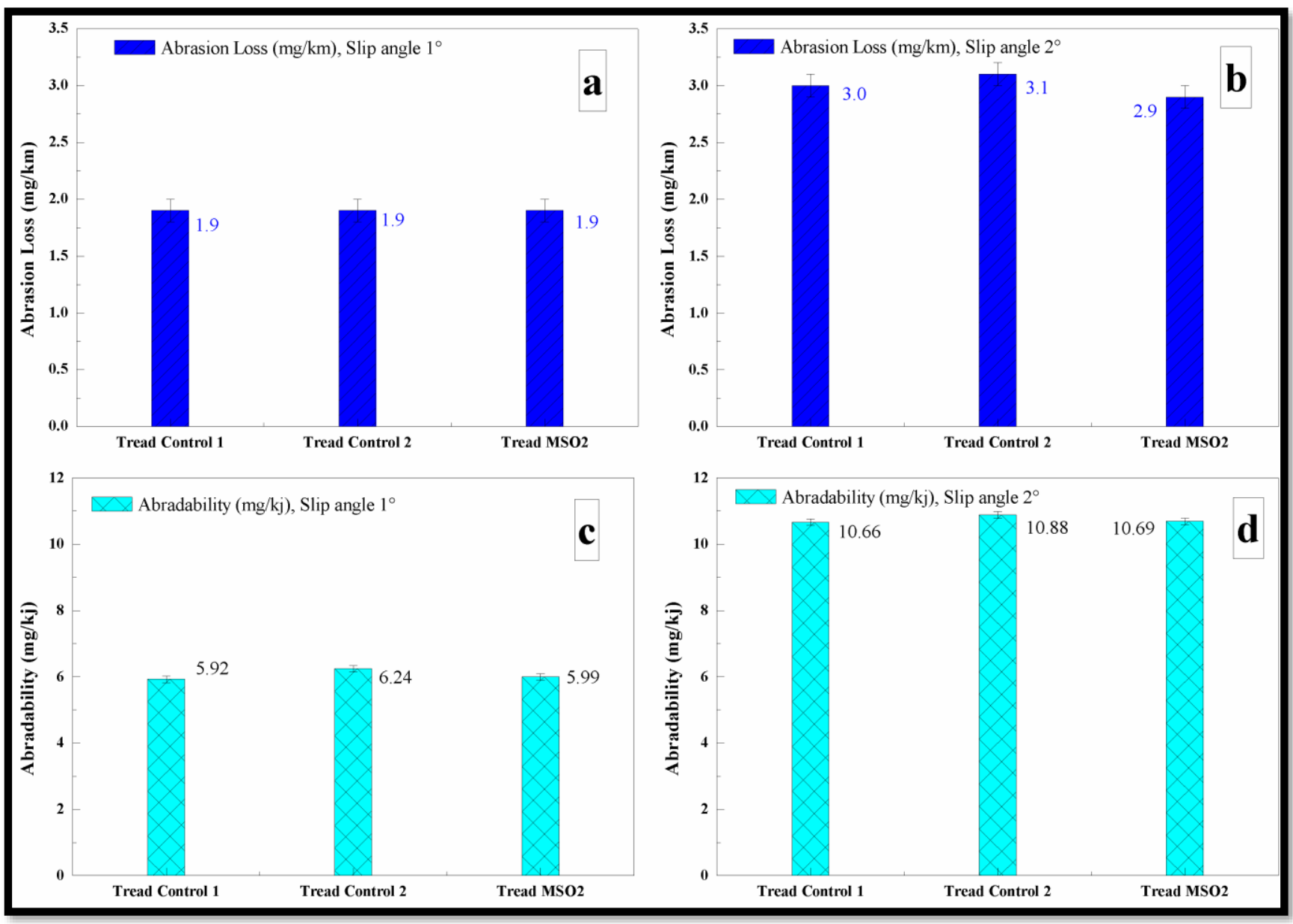

Figure 11: Abrasion loss at Speed: $20 \mathrm{~km} / \mathrm{h}$, Load: $40 \mathrm{~N}$ (a) Slip angle: $1^{\circ}$ and (b) Slip angle: $2^{\circ}$, (c) Abradability at Speed : $20 \mathrm{~km} / \mathrm{h}$, Load : $40 \mathrm{~N}$, Slip angle: $1^{\circ}$ and (d) slip angle: $2^{\circ}$

Above figure signifies that the compound has been tested with two numbers of control compounds to check the variation in between control compounds. Abrasion is basically a volume loss of rubber by abrading with rough surface with different angle and variable load. The wear analysis have done in $1^{\circ}$ and $2^{\circ}$ slip angle and 40N and 20N load, for MSO2 compound has been shown in Figure 11 a,b where as abradability index has been performed with above configuration shown in Figure $11 \mathrm{c}, \mathrm{d}$. Here Wear performance tolerance level was considered as a $10 \%$ of control compound. On the basis of above analysis we got better abrasion resistance value for MSO2 compound. The same phenomena also noticed in terms of abradability index.

The reason behind of above phenomena is to be considered as better polymer filler interaction rather than filler -filler interaction. On the other way we can say that the dynamic stiffness of MSO2 compound is also a reason for better wear properties, higher the dynamic stiffness value import better wear resistance while rotating in rough surface. Better dynamic stiffness (E') reflects the better compatibility with non polar rubber and plasticizers. At a constant load and constant speed the MSO2 compound has given better wear properties due to have better dispersion to rubber matrix.

\section{CONCLUSION}

In this work the performance of soybean oil as well as TRAE oil in composition with natural rubber and synthetic rubber (s-SBR and PBR) were evaluated. However substantial changes were observed when the soybean oil was incorporated in elastomeric composition. TGA confirms that in this oil have several unsaturated fatty acids and antioxidants. The Payne effect value corroborates with this result, the composition with soybean oil presented the biggest difference in the modulus at high and low strain which indicates high filler-filler interaction breakup with increasing strain percentage. Dispersion studies also conclude that no significant changes were observed by the replacement of TRAE oil with Soybean oil. This finding promotes a way to utilise sustainable oil to upgrade future tyre technology. 


\section{Acknowledgement}

The authors are very grateful to the Hari Shankar Singhania Elastomer and Tyre Research Institute (HASETRI) for the great support and permission in publishing this research work.

\section{References}

[1] Reincke, Katrin, W. Grellmann, and J. Friedel. "Influence of process oils on the mechanical properties of elastomers." Kautsch Gummi Kunstst 62, no. 10 (2009): 506-514.

[2] Kuta, A., Z. Hrdlicka, J. Voldanova, J. Brejcha, and J. Pokorny. "Dynamic Mechanical Properties of Rubbers with Standard Oils and Oils with Low Content of Polycyclic Aromatic Hydrocarbons." KGK. Kautschuk, Gummi, Kunststoffe 63, no. 4 (2010): 120-122.

[3] Bowman, J., M. Da Via, M. E. Pattnelli, and P. Tortoreto. "The influence of non-toxic extender oil on SBR performances." Kautschuk Gummi Kunststoffe 57, no. 1-2 (2004): 31-36.

[4] Xu, Haoshu, Tao Fan, Neng Ye, Weidong Wu, Daye Huang, Danling Wang, Zhao Wang, and Liqun Zhang. "Plasticization Effect of Bio-Based Plasticizers from Soybean Oil for Tyre Tread Rubber." Polymers 12, no. 3 (2020): 623-633

[5] Dasgupta, S., S. L. Agrawal, S. Bandyopadhyay, S. Chakraborty, R. Mukhopadhyay, R. K. Malkani, and S. C. Ameta. "Characterization of eco-friendly processing aids for rubber compound." Polymer Testing 26, no. 4 (2007): 489-500

[6] Niewiadomski, Henryk. Rapeseed. Chemistry and technology. Elsevier, 1990.

[7] Sahakaro, Kannika, and Amnuwa Beraheng. "Epoxidized natural oils as the alternative safe process oils in rubber compounds." Rubber chemistry and technology 84, no. 2 (2011): 200-214

[8] Schmucker, Johanna, and Celina Schwarz. "Promoting the development of sustainable transportation Infrastructure" Economic and Social Council, MUNOBB 2020.

[9] Sutton, Philip. "A perspective on environmental sustainability." Paper on the Victorian Commissioner for Environmental Sustainability (2004): 1-32

[10] Pragastis, Peter, Iqbal Sihra, and Michael N. Granieri. "Synthetic instrumentation: Contemporary architectures and applications (part ii)." RFDESIGN/Defense Electronics Supplement (2004): 12-19.

[11] Petrović, Zoran S., Mihail Ionescu, Jelena Milić, and James R. Halladay. "Soybean oil plasticizers as replacement of petroleum oil in rubber." Rubber chemistry and technology 86, no. 2 (2013): 233-249.

[12] Ismail, Hanafi, H. Anuar, and Y. Tsukahara. "Effects of palm oil fatty acid on curing characteristics, reversion and fatigue life of various natural rubber compounds." Polymer international 48, no. 7 (1999): 607-613.

[13] Dasgupta, S., S. L. Agrawal, S. Bandyopadhyay, R. Mukhopadhyay, R. K. Malkani, and S. C. Ameta. "Eco-friendly processing oils: A new tool to achieve the improved mileage in tyre tread." Polymer Testing 28, no. 3 (2009): 251-263.

[14] Niewiadomski, Henryk. Rapeseed. Chemistry and technology. Elsevier, 1990.

[15]. Norwood IV, Verrill M. "Introduction of Natural Oils into Rubber Compounds." (2014).

[16] Environmental, Shimadzu. "and Social Report 2010."

[17] Sahakaro, Kannika, and Amnuwa Beraheng. "Epoxidized natural oils as the alternative safe process oils in rubber compounds." Rubber chemistry and technology 84, no. 2 (2011): 200-214.

[18] Hayichelaeh, C., L. A. E. M. Reuvekamp, W. K. Dierkes, A. Blume, J. W. M. Noordermeer, and K. Sahakaro. "silica-reinforced natural rubber tyre tread compounds containing bio-based process oils. ii: influence of epoxide and amino functional groups." Rubber Chemistry and Technology 93, no. 1 (2020): 195-207.

[19] Sahakaro, Kannika, and Amnuwa Beraheng. "Epoxidized natural oils as the alternative safe process oils in rubber compounds." Rubber chemistry and technology 84, no. 2 (2011): 200-214.

[20] Zanchet, Aline, Pamela S. Garcia, Regina CR Nunes, Janaina S. Crespo, and Carlos H. Scuracchio. "Sustainable natural rubber compounds: naphthenic oil exchange for another alternative from renewable source." Int. Ref. J. Eng. Sci. 4 (2016): 10-19.

[21] Zanchet A, Garcia PS, Nunes RC, Crespo JS, Scuracchio CH. Sustainable natural rubber compounds: naphthenic oil exchange for another alternative from renewable source. Int. Ref. J. Eng. Sci.. 2016;4:10-19.

[22] Petrović, Zoran S., Mihail Ionescu, Jelena Milić, and James R. Halladay. "Soybean oil plasticizers as replacement of petroleum oil in rubber." Rubber chemistry and technology 86, no. 2 (2013): 233-249.

[23] Nandanan, V., Rani Joseph, and D. J. Francis. "Linseed oil as a multipurpose ingredient in NBR vulcanizate." Journal of Elastomers \& Plastics 28, no. 4 (1996): 326-334. 